\title{
Small intestinal histochemical and histological changes in ulcerative colitis
}

\author{
N. JANKEY AND L. A. PRICE \\ From the Gordon Hospital, London
}

In the gastrointestinal tract, ulcerative colitis is usually considered to involve only the large gut, apart from a non-specific reflux terminal ileitis. However, it has recently been shown that structural and functional changes occur in the small intestine during attacks of ulcerative colitis (Salem and Truelove, 1965). In a study of 60 colitics, these authors showed increased faecal fat excretion and impaired d-xylose excretion. They also described varying abnormalities of villous pattern and some degree of enzyme deficiency. They thought that the villous abnormalities probably did not cause the malabsorption and suggested that small intestinal malfunction in colitis might be explained either by enzyme deficiency or by changes in small intestinal motility. We have studied biopsies from 10 colitic and seven non-colitic patients by histochemical and microscopic techniques to see if these findings can be confirmed.

\section{PATIENTS STUDIED}

The patients were drawn from those attending the Gordon Hospital between 1965 and 1968. They were divided into two groups: 10 definite colitics and seven definite non-colitics.

GROUP I: COLITICS Every patient in this group conformed to all the following criteria: a typical history, characteristic barium enema changes, typical sigmoidoscopic appearances, and unequivocal histological appearances on rectal biopsy. In addition, confirmatory postcolectomy macroscopic and microscopic changes were found in six cases. Any patient with the slightest microscopic evidence of Crohn's disease was excluded. In all these patients the colitis was in an acute phase when the biopsy was taken.

GROUP II: NON-COLITICS These were patients undergoing investigations for diarrhoea. In every case in this group, barium enema, barium meal and follow-through, sigmoidoscopy, faecal fat excretion, and d-xylose excretion were all normal. None of the criteria defined for the colitic group was present in any of these patients, and they are regarded as controls for the purposes of this study.

In neither group was there any evidence of any other major disease.

\section{METHODS}

The specimens used were peroral jejunal biopsies obtained by a Carey capsule under radiographic control. Each biopsy was examined by three methods: (1) with a dissecting microscope; (2) by light microscopy of haematoxylin-and-eosin-stained preparations, for which 20 serial biopsies were cut on each specimen and every fifth section was stained and examined; (3) histochemically, for which all 17 specimens were 'stained' for alkaline phosphatase, acid phosphatase, non-specific esterase, succinic dehydrogenase and leucinaminopeptidase, glucose 6-phosphate dehydrogenase, and monoamine oxidase. In addition, the seven non-colitics and five colitics were examined for iso-citric dehydrogenase. Fresh frozen material sectioned on a cryostat was used in this study. The methods used were those described by Pearse (1960). The enzyme reactions were graded subjectively. The strongest reaction was recorded as +++ and a just visible reaction as \pm . Intermediate grades were graded ++ and + .

\section{RESULTS}

With the dissecting microscope, biopsies from all seven non-colitics showed normal finger-like to leaf-shaped villi, and four of those from the 10 colitics a convoluted mucosal pattern (Table I).

With haematoxylin-and-eosin-stained sections there were no mucosal abnormalities in any of the noncolitics as judged by light microscopy. However, partial villous atrophy was found in four of the 10 colitics (Table I).

There were no histochemical differences between the two groups (Table II). The results with isocitrate dehydrogenase showed no differences between the seven non-colitics and the five colitics. 
TABLE I

HISTOLOGICAL APPEARANCES

Case No. Dissecting Microscope Appearances Histological Sections

\begin{tabular}{rll}
\hline Non-colitic & & \\
1 & Finger-like villi & Normal \\
2 & Finger-like villi & Normal \\
3 & Finger-like villi & Normal \\
4 & Finger-like villi & Normal \\
5 & Finger-like villi & Normal \\
6 & Finger-like and leaf-shaped villi & Normal \\
7 & Finger-like villi & Normal \\
& & \\
Colitic & & \\
8 & Finger-like and leaf-shaped villi & Normal \\
9 & Finger-like and leaf-shaped villi & Normal \\
10 & Finger-like villi & Normal \\
11 & Finger-like villi & Normal \\
12 & Finger-like and leaf-shaped villi & Normal \\
13 & Finger-like villi & Normal \\
14 & 'Convoluted' & Partial villous atrophy \\
15 & 'Convoluted' & Partial villous atrophy \\
16 & 'Convoluted' & Partial villous atrophy \\
17 & 'Convoluted' & Partial villous atrophy
\end{tabular}

DISCUSSION

The histological results in this study confirm the expected changes in the small intestines of the colitic group. Salem and Truelove (1965) showed that the degree of partial villous atrophy was greatest in the more severely ill colitics and this too is the case in our series. These authors also describe one patient whose small intestinal function returned towards the normal after colectomy, thus suggesting that the small intestinal changes in ulcerative colitis are secondary to primary disease of the colon. However, in view of the enormous functional reserve of the small intestine, they suggested that certain enzyme deficiencies occurring during an acute attack of colitis might be responsible for the observed malabsorption of fat and impaired d-xylose excretion. They studied five cases histochemically and in three of these showed a reduction of small intestinal acid phosphatase. Some other unspecified enzymes were said to be deficient in some of the colitics.

We have, however, been unable to demonstrate any difference histochemically between the 10 colitic and the seven non-colitic patients. Since all our colitics were acutely ill (six underwent colectomy within a few days of jejunal biopsy), any enzyme differences might reasonably be expected to be apparent at the time the study was made. Since these changes were absent, we feel that deficiency of the enzymes studied is unlikely to be a cause of small intestinal malfunction in ulcerative colitis. It may be that a combination of altered motility, as suggested by Salem and Truelove, and partial villous atrophy is sufficient to produce malabsorption sufficiently gross to be detected by faecal fat and d-xylose studies. The question could probably be decided by a study correlating enzyme studies with malabsorption studies in a larger series.

\section{SUMMARY}

Small intestinal biopsies from 10 colitic and seven non-colitic patients were compared histologically and histochemically. Histologically, no abnormalities were seen in the non-colitic group but four of the colitics showed partial villous atrophy and a convoluted mucosal pattern under the dissecting

TABLE II

HISTOCHEMICAL RESULTS

\begin{tabular}{|c|c|c|c|c|c|c|c|}
\hline \multirow[b]{2}{*}{ Case No. } & \multicolumn{7}{|l|}{ Enzyme } \\
\hline & $\begin{array}{l}\text { Alkaline } \\
\text { Phosphatase }\end{array}$ & $\begin{array}{l}\text { Acid } \\
\text { Phosphatase }\end{array}$ & $\begin{array}{l}\text { Non-specific } \\
\text { Esterase }\end{array}$ & $\begin{array}{l}\text { Succinic } \\
\text { Dehydrogenase }\end{array}$ & $\begin{array}{l}\text { Leucinamino } \\
\text { Peptidase }\end{array}$ & $\begin{array}{l}\text { Glucose-6 } \\
\text { Phosphate } \\
\text { Dehydrogenase }\end{array}$ & $\begin{array}{l}\text { Monoamine } \\
\text { Oxidase }\end{array}$ \\
\hline \multicolumn{8}{|l|}{ Non-colitic } \\
\hline 1 & $+t+$ & ++ & ++ & ++ & +++ & +++ & ++ \\
\hline 2 & ++ & ++ & ++ & ++ & ++ & $++t$ & ++ \\
\hline 3 & $+t$ & ++ & $++t$ & ++ & $++t$ & + & + \\
\hline 5 & $++t$ & \pm & $+t$ & + & + & \pm & \pm \\
\hline 6 & \pm & ++ & $++t$ & ++ & $+t$ & ++ & ++ \\
\hline 7 & ++ & ++ & $+t+$ & + & ++ & + & + \\
\hline \multicolumn{8}{|l|}{ Colitic } \\
\hline 8 & ++ & $+t$ & ++ & + & + & + & + \\
\hline 9 & ++ & $+t+$ & ++ & + & $+t+$ & ++ & ++ \\
\hline 10 & ++ & ++ & +++ & + & $+t+$ & + & + \\
\hline 11 & + & ++ & $++t$ & $+t$ & ++ & + & ++ \\
\hline 13 & ++ & + & ++ & ++ & ++ & ++ & ++ \\
\hline 14 & ++ & $+t+$ & $++t$ & $+t+$ & +++ & +++ & $++t$ \\
\hline 15 & ++ & +++ & ++ & $+t$ & + & + & ++ \\
\hline 16 & + & $+t$ & ++ & + & ++ & \pm & + \\
\hline 17 & + & ++ & + & + & ++ & $\bar{t}$ & + \\
\hline
\end{tabular}


microscope. Histochemically, no difference was found between the two groups for any of the enzymes studied. There is no evidence in this series of any small intestinal enzyme deficiency in ulcerative colitics. It is, therefore, thought unlikely that enzyme deficiency is a cause of the malabsorption which occurs in acute attacks of ulcerative colitis.
We are very grateful to $\mathrm{Dr} R$. D. Tonkin for permission to study patients under his care, and to Dr I. M. P. Dawson for encouragement with this project.

\section{REFERENCES}

Salem, S. N., and Truelove, S. C. (1965). Small-intestinal and gastric abnormalities in ulcerative colitis. Brit. med.J., 1, 827-831.

Pearse, A. E. (1960) Histochemistry, Theoretical and Applied, 2nd ed. Churchill, London. 